\title{
Psychometric Properties and Factor Structure of the Brief Religious Coping Scale (Brief-RCOPE) in Puerto Rican Adults
}

\author{
Propiedades psicométricas y estructura factorial de la Escala Breve \\ de Afrontamiento Religioso (Brief-RCOPE) en adultos puertorriqueños
}

\author{
Orlando M. Pagán-Torres * 1,2, Eduardo Cumba-Avilés ${ }^{3}$, \\ Ernesto Rosario-Hernández ${ }^{4}$, Juan Aníbal González-Rivera ${ }^{2}$ \\ 1 - Albizu University, San Juan Campus, Puerto Rico. \\ 2 - Ponce Health Sciences University, San Juan University Center, Puerto Rico. \\ 3 - Institute for Psychological Research, University of Puerto Rico, Rio Piedras Campus. \\ 4 - Ponce Health Sciences University, Ponce, Puerto Rico.
}

Introduction

Method

Results

Discussion

Conclusion

References

Recibido: 12/01/2021 Revisado: 12/03/2021 Aceptado: 21/03/2021

\begin{abstract}
This research examines the psychometric properties and factor structure of the Brief Religious Coping Scale (Brief-RCOPE) in a sample of 302 Puerto Rican adults. We examined its internal consistency (Cronbach's alpha), McDonald's omega coefficient, construct validity, and factor structure. The Brief-RCOPE obtained an alpha coefficient of .94 in the Positive Religious Coping (PRC) subscale and .84 in the Negative Religious Coping (NRC) subscale. The omega coefficient was .94 (PRC) and .85 (NRC), respectively. We conducted a confirmatory factor analysis, using the Satorra-Bentler correction, to examine the factor structure of the Brief-RCOPE. The two-factor model showed a better adjustment to the data than the one-factor model. Indicators of construct validity were also adequate. Our findings suggest that the Brief-RCOPE is a reliable and valid instrument to measure religious coping strategies that may significantly affect people's daily lives.
\end{abstract}

Keywords: factor structure, Puerto Rican, psychometric properties, religious coping, religiousness

\section{Resumen}

Esta investigación examina las propiedades psicométricas y estructura factorial de la Escala Breve de Afrontamiento Religioso (Brief-RCOPE) en una muestra de 302 adultos puertorriqueños. Examinamos la consistencia interna (alfa de Cronbach), el coeficiente omega de McDonald, la validez de constructo y la estructura factorial. La Brief-RCOPE obtuvo un coeficiente alfa de .94 en la subescala de afrontamiento religioso positivo (ARP) y de .84 en la de afrontamiento religioso negativo (ARN). El coeficiente omega fue de .94 (ARP) y .85 (ARN), respectivamente. Realizamos análisis factorial confirmatorio mediante la corrección de Satorra-Bentler, para examinar la estructura factorial de la Brief-RCOPE. El modelo de dos factores mostró un ajuste a los datos superior al modelo unifactorial. Los indicadores de validez de constructo también fueron adecuados. Nuestros hallazgos sugieren que la Brief-RCOPE es un instrumento confiable y válido para medir estrategias de afrontamiento religioso que podrían afectar significativamente la vida diaria de las personas.

Palabras clave: afrontamiento religioso, estructura factorial, puertorriqueños, propiedades psicométricas, religiosidad

\footnotetext{
*Author's note: The authors have no conflict of interest to disclose.

Correspondence to: Orlando M. Pagán Torres, Assistant Professor at Ponce Health Sciences University and Adjunct Professor at Albizu University. E-mail: opagan@psm.edu How to cite: Pagán-Torres, O. M., Cumba-Avilés, E., Rosario-Hernández, E., \& González-Rivera, J. A. (2021). Psychometric properties and factor structure of the Brief Religious Coping Scale (Brief-RCOPE) in Puerto Rican adults. Revista Evaluar, 21(2), 48-62. Recuperado de https://revistas.unc.edu.ar/index.php/revaluar Participaron en la edición de este artículo: Eva Crasso, Fiorella Garabano, Gloria Nieve, Alicia Molinari, Eugenia Barrionuevo, Facundo Varela, Florencia Ruiz, Benjamín Casanova, Ricardo Hernández.
} 


\section{Introduction}

Research studies reveal that religious/spiritual involvement is associated with better health (Koenig, 2012, 2015; Oman \& Syme, 2018). The documented findings concerning the impact of religious/spiritual involvement on health are closely associated with the use of religious coping (RC) strategies (Gerber, Boals, \& Schuettler, 2011; Gonçalves, Lucchetti, Menezes, \& Vallada, 2015; Pargament, 1997). RC is a strategy based on religious beliefs and practices to prevent and alleviate the negative consequences of stressful events (Pargament, 1997).

Religiosity is a relevant dimension of Puerto Ricans' culture and lifestyle. According to the Pew Research Center survey (2014), 89\% of Puerto Ricans living on the island self-perceive as Christians, distributed in Catholic Christians with $56 \%$, followed by Protestant Christians with $33 \%$, while $8 \%$ are unaffiliated and $2 \%$ who identify themselves as "other", which could include minority religious groups. Therefore, it is not surprising that religious and spiritual beliefs play a significant role in the majority of Puerto Ricans' daily life and culture (Agosto-Cintrón, 1996; Scarano, 2008).

There are several reasons to argue the importance of measuring the religious and spiritual dimensions. First, research reveals that these dimensions can affect people's health in physical, emotional and social aspects when used as positive or negative coping mechanisms (Bonelli \& Koenig, 2013; Koenig, 2012; Oman \& Syme; 2018). Second, on many occasions, the main complaint of patients/clients who attend therapy is related to religious/spiritual aspects (American Psychiatric Association, 2013). Therefore, the measurement of these constructs will provide more information on the role of religious and spiritual dimensions in people's lives. Third, a close examination of religiosity and religious coping strategies could help us understand the global vision of the patient/client and strengthen the therapeutic relationship (Richards \& Bergin, 2014). Fourth, the information obtained could be relevant in the development of a treatment plan consistent with the needs of the client/patient (Richard \& Bergin, 2014). Last, the assessment of these dimensions could help professionals understand the role of spirituality and religiosity in client/patient health care (Gonçalves et al., 2015).

Pargament (1997) defines coping as "the search for meaning in times of stress" (p. 90). In addition, religious coping is defined as the different ways of understanding and handling negative life events that are related to the sacred (Pargament \& Raiya, 2007). Pargament (1997) originally developed the religious coping construct. This author proposes that religion is one of the ways in which individuals can cope with their life situations through positive and negative strategies that emerge from their religious beliefs and practices. Pargament, Koenig and Perez (2000) developed the first validated instrument to measure religious coping: The Religious Cope (RCOPE). This scale, in its original form, had 105 items distributed in 21 sub-scales. As reported in the study, the reliability estimates of the instrument subscales were high. Specifically, the RCOPE showed a Cronbach alpha internal consistency of .80 or more for all subscales except for two dimensions: marking the religious limits (.78) and the reassessment of the power of God (.61)

Later, a short version of the RCOPE was developed. The Brief Religious Coping Scale (Brief-RCOPE) includes 14 items as a result of conducting several exploratory factor analyses (EFA) with different samples (Pargament, Smith, Koenig, \& Perez, 1998; Pargament, Feuille, \& Burdzy, 2011). This measure has the advantage of measuring religious coping strategies in a short 
time. The scale consists of 14 items in four-point Likert-type format ranging from Not at all to Very much. The items are distributed in two dimensions classified as positive religious coping (PRC) and negative religious coping (NRC), as shown by both EFA and a confirmatory factor analysis (CFA) conducted by the authors on two samples (Pargament et al., 1998). The model fit indexes obtained for the CFA two-factor model were adequate. In their review, Pargament et al. (2011) reported that Cronbach's alphas for the NRC were generally lower than those for PRC, with median values for the PRC scale being .92 and .081 for the NCR.

The psychometric properties and factor structure of the Brief RCOPE have been examined in a diversity of countries and populations. For instance, in a sample of 403 Iraqi secondary school students, and following a principal component analysis (PCA), with both varimax and oblimin rotations, PRC and NRC subscales had Cronbach's alphas of .86 and .82, respectively (Al-Hadethe, Hunt, Thomas, \& Al-Qaysi, 2016). Also using a PCA but with a promax rotation, Mohammadzadeh and Najafi (2016) examined the structure of the Persian version of the Brief RCOPE among 339 Iranian university students (mean age $=27.30$ years). They reported alpha coefficients of .79 for the PRC and .71 for the NRC components extracted, using the eigenvalue $>1.0$ criteria. The components showed the same item organization as the original English version. In these two previous studies, the authors did not report the correlation among the components or the observed subscales scores. On the other hand, in three Greek-Orthodox samples, and using an EFA with unweighted least squared extraction and promin oblique rotation, the B-RCOPE showed a two-dimensional factor structure with remarkable stability across the samples corresponding to the PRC (Factor 1) and NRC (Factor 2) dimensions.
Cronbach's alphas were $.91-.96$ and $.77-.92$ for the PRC and NRC factors, respectively (Paika et al., 2017). The authors reported factor inter-correlations ranging from .33 to .51 in the sub-samples, and a value of . 44 for the entire sample. In 2 out of 3 sub-samples, and in the combined sample, item 13 (demonic reappraisal) showed higher loadings on Factor 1, although a higher loading on Factor 2 was expected.

The complexity of the loadings of item 13 was also documented in a study with 170 Brazilian adults with end-stage renal disease, in which the PRC $(\alpha=.83)$ and $\operatorname{NRC~}(\alpha=.75)$ dimensions were identified after a PCA with varimax rotation (Ramirez et al., 2012). No data was reported on components inter-correlation. In another study conducted in Brazilian adults (Esperandio, Escudero, Fernandes, \& Pargament, 2018), the authors split the sample in two: one for conducting an EFA $(n=249)$ and the other $(\mathrm{n}=276)$ to perform a CFA. In the EFA sample (principal axis factoring extraction with varimax rotation), a two-factor solution was reported, with alpha coefficients of .89 and .85 for the PRC and the NRC, respectively. This factor structure was tested with a CFA in the second sample and adequate model fit indexes were observed. In addition, an average variance extracted of .50 (minimum size recommended) was found for each factor, with a composite reliability of .87 for the PRC and .84 for the NRC. Data on the inter-factor correlation was not provided, nor the path diagram of the CFA, although the factors were considered orthogonal in the EFA. In a third study conducted with a Brazilian Portuguese version, Freitas et al. (2015) used the Brief RCOPE in 147 adults (73.5\% Roman Catholics) with inflammatory bowel disease. The authors conducted a PCA with varimax rotation and an eigenvalue $>$ 1.5 as the criteria for component retention. Two components were retained which were consistent 
with the PRC (Factor 1, $\alpha=.87$ ) and NRC (Factor $2, \alpha=.74$ ) dimensions. Item 14 (Questioned the power of God) showed the lowest loading with its respective component (.31). The authors kept this item even when it did not meet their cut-off criteria (a loading $\geq .40$ ).

Spanish versions of the Brief-RCOPE have been used at least for the past 14 years. As far as can be ascertained, the first Spanish version of this measure was developed by Rivera-Ledesma and Montero-López (2007). In two samples (sample $1, \mathrm{n}=129$; sample 2, $\mathrm{n}=209$ ) of Mexican adults aged 50 and over ( $88 \%$ Catholics), these authors found internal consistency (alpha) values ranging from .82 to .83 for the PRC and from .60 to .65 for the NRC. When they removed item 13 from the NRC subscale, its alpha values were .62 and .67 , respectively. The authors then submitted data from the larger sample to a PCA with varimax rotation, using the eigenvalue $>1.0$ criteria to determine the number of components. Although they found four components in the initial analysis, only the PRC showed a configuration identical to the original version. Only three items loaded on the NRC component, yielding an alpha coefficient of .50. The internal consistency of the PRC ( $\alpha=$ $.83)$ and NRC $(\alpha=.61)$ was also reported in a study in which Robles-García et al. (2014) used the Spanish Brief RCOPE in a sample of Mexican patients with paranoid schizophrenia. However, in this study, the factor structure of the scale was not examined. Martinez and Sousa (2011), on their behalf, used a Spanish version of the scale in a sample of 121 Mexican-American adults with type 2 diabetes ( $82 \%$ Catholics). In their first PCA, they found three factors with eigenvalues $>1.0$, with the third factor being composed by items 6 and 7. After excluding those items, additional PCAs (with oblimin and varimax rotations) revealed a two-component solution in which item 13 did not load onto any of them. Cronbach's alpha values for the 5-tem PRC and the 6-item NRC were of .85 and .86 , respectively.

However, the Brief-RCOPE bifactor structure was replicated in a sample of 442 Spanishspeaking Chileans aged 18 to 83 years who had been exposed to traumatic events (García, Oyanedel, Páez, \& Arias, 2021). The measure obtained a Cronbach's alpha of .94 for the PRC subscale and .79 for the NRC dimension. In this study, the authors used a CFA with the robust weighted least square estimation due to the lack of multivariate normality of the data. Model fit indexes yielded excellent results. The correlation among the PRC and NRC factors was .35. In a fifth study conducted with a Spanish version of the scale, Mezzadra and Simkin (2017) used the Brief RCOPE with 200 Catholic students from Buenos Aires, Argentina (aged 14 to 18 years). The authors analyzed data with a polychoric correlation matrix using a CFA and obtained adequate goodness of fit indexes for a two-factor structure. Alpha coefficients for the PRC and NRC were .83 and .72 , respectively.

The scientific study of religion and spirituality from a mental health perspective in Puerto Rico has increased in recent years (GonzálezRivera et al., 2019; Pagán-Torres, SánchezGalarza, Tollinchi-Natali, \& González-Rivera, 2017). Currently, there are wide varieties of religious and spiritual measures validated with Puerto Rican samples (Pagán-Torres \& GonzálezRivera, 2019). Recently, González-Rivera and Pagán-Torres (2018) validated in Puerto Rico a religious coping scale with 350 adult participants. The measure obtained a Cronbach's alpha internal consistency of .95. This scale is based on the Lazarus and Folkman (1986) Transactional Model of Stress and Coping, which conceptualizes coping styles in two dimensions: internal and external coping strategies. The first study in which a Spanish version of the Brief RCOPE was used in 
Puerto Rico was conducted with a sample of 70 Puerto Rican adult patients (61\% Catholics) with cancer (Rodríguez-Carrión, Sayers-Montalvo, \& Martínez-Taboas, 2011). Nevertheless, no data about the psychometric performance of the scale in that sample was provided. Years later, ColónRivera (2014) translated into Spanish and validated the Brief RCOPE with 226 Puerto Rican adults. The psychometric properties of the instrument revealed a reliability coefficient of .93 for the PRC subscale, and .88 for the NRC subscale. However, the factor structure of the Brief RCOPE has not been explored in a sample of Puerto Ricans.

Therefore, this study has the following aims. First, (a) to examine the factor structure (unidimensional or multidimensional) of the Brief RCOPE, using CFA with the maximum likelihood estimation, in a sample of Puerto Rican adults, given thatthe state of the research literature reflects a lack of evidence on the factor structure of the Brief RCOPE in Puerto Ricans (PagánTorres \& González-Rivera, 2019). Second, (b) to examine the reliability of the Brief RCOPE through Cronbach's alpha internal consistency and McDonald's omega coefficient. Third, (c) to evaluate the corrected item-total correlation of each item and concurrent validity of each subscale. Finally, (d) to examine the construct validity, through the evidence of its convergent and discriminant validity, using the average variance extracted (AVE) and related statistics.

\section{Method}

Research design and procedures

This research has an instrumental design consisting of a one-time assessment. This is a secondary analysis from a research study authorized by the Institutional Review Board (IRB) from Ponce Health Sciences University, Ponce,
Puerto Rico (protocol \#1902005352). Once the IRB authorization was obtained, the recruitment of the participants began. The digital platform PsychData was employed to collect the online survey data. Online recruitment was achieved through the sharing of study information via social networks and emails. When the participants accessed the survey link, they proceeded to read the informed consent form, which explained all the information, the purpose, the procedures, and the benefits and risks of the research. If the participants agreed to participate, they proceeded to communicate their consent in the space provided in the digital form. In order to guarantee the protection of confidentiality, only an identification code was assigned in the database to record the data of the participants, but no identifying data was collected. After completing the informed consent form, participants proceeded to complete the sociodemographic data form, as well as the study measures.

\section{Participants}

A non-probabilistic recruitment strategy was applied. The convenient sample consisted of 302 Puerto Rican adults. The sample average age was 35.79 years $(\mathrm{SD}=12.14)$. The inclusion criteria were: (1) being 21 years of age or older, (2) possessing the ability to read and understand Spanish, (3) being Puerto Rican, and (4) being a resident of Puerto Rico. Table 1 shows the full sociodemographic characteristics of the participants.

\section{Measures}

Sociodemographic Data Form. This document included questions aimed to explore the profile of 
Table 1

Sociodemographic Characteristics of the Sample.

\begin{tabular}{|c|c|c|c|c|c|}
\hline Demographics & $f$ & $\%$ & & & \\
\hline \multicolumn{6}{|l|}{ Sex } \\
\hline Male & 78 & 25.8 & Religious Affiliation & & \\
\hline Female & 224 & 74.2 & Catholic & 124 & 41.1 \\
\hline Age & & & $\begin{array}{l}\text { Protestant (Evangelical, } \\
\text { Methodist, Baptists, } \\
\text { Pentecostal) }\end{array}$ & 116 & 38.4 \\
\hline $21-29$ & 134 & 44.2 & Adventist & 2 & 0.7 \\
\hline $30-39$ & 66 & 21.9 & Islamism (Muslim) & 1 & 0.3 \\
\hline $40-49$ & 48 & 15.9 & Buddhism & 5 & 1.7 \\
\hline $50-59$ & 41 & 13.8 & Santería & 1 & 0.3 \\
\hline $60-69$ & 11 & 3.6 & None & 53 & 17.5 \\
\hline \multirow[t]{2}{*}{$70-71$} & 2 & 0.6 & & & \\
\hline & & & Importance of Religion & & \\
\hline Marital Status & & & Nothing & 36 & 11.9 \\
\hline Single & 148 & 49.0 & Somewhat & 57 & 18.9 \\
\hline Married & 102 & 33.8 & Important & 80 & 26.5 \\
\hline Widowed & 3 & 1.0 & Very important & 129 & 42.7 \\
\hline Divorced & 18 & 6.0 & & & \\
\hline \multirow[t]{2}{*}{ Cohabiting (free union) } & 31 & 10.3 & Participation in religious activities & & \\
\hline & & & Never & 59 & 19.5 \\
\hline Annual Income (USD) & & & Once a year & 79 & 26.2 \\
\hline$\$ 0-20,000$ & 150 & 49.7 & Monthly & 44 & 14.6 \\
\hline$\$ 21,000-30,000$ & 47 & 15.6 & Weekly & 107 & 35.4 \\
\hline$\$ 31,000-40,000$ & 34 & 11.3 & Daily & 13 & 4.3 \\
\hline$\$ 41,000-50,000$ & 13 & 4.3 & & & \\
\hline$\$ 51,000-60,000$ & 18 & 6.0 & \multirow{2}{*}{$\begin{array}{l}\text { Participation in private religious } \\
\text { activities }\end{array}$} & & \\
\hline \multirow[t]{2}{*}{$\$ 61,000$ or more } & 40 & 13.2 & & & \\
\hline & & & Never & 60 & 19.9 \\
\hline Academic Preparation & & & Once a year & 28 & 9.3 \\
\hline High school or less & 14 & 4.6 & Monthly & 25 & 8.3 \\
\hline Associate degree/technical & 13 & 4.3 & Weekly & 53 & 17.5 \\
\hline Bachelor's degree & 84 & 27.8 & Daily & 136 & 45.0 \\
\hline Master's degree & 102 & 33.8 & Note. $\mathrm{N}=302$. & & \\
\hline Doctoral degree & 89 & 29.5 & & & \\
\hline
\end{tabular}


the study participants such as the age, marital status, gender, annual income, religious affiliation, importance assigned to religion, participation in religious activities, and participation in private religious practices.

\section{Brief Religious Coping Scale (Brief-RCOPE;} Pargament et al., 1998). To measure religious coping, we used the Brief Scale of Religious Strategies (Brief RCOPE) described by Pargament et al., (2011). We used the Spanish version validated in the Puerto Rican population by ColónRivera (2014). The inventory measures PRC and NRC strategies based on the Pargament (1997) theoretical model. The instructions of the BriefRCOPE invite participants to think about the most stressful event they have experienced in the last year. Then, the scale presents a list of $14 \mathrm{RC}$ strategies (e.g., I looked for God's love and care; I looked for God's help to release my courage; I wondered if God had abandoned me), and ask the respondent to indicate, on a four-point Likert-type response scale, the degree to which each strategy applied to them: 1 (Not at all), 2 (Somewhat), 3 (Quite a bit) and 4 (Very much).

\section{Data analyses}

The IBM SPSS version 27.0 program (IBM Corp., 2020) was used to perform most statistical analyses. Descriptive statistics were calculated through measures of central tendency (mean, mode and median) and use of percent and frequencies, to explore the sociodemographic characteristics of the sample. In addition, the items' discrimination index through corrected item-total correlation $\left(r_{\text {bis }}\right)$ were considered. Those items with correlations magnitudes greater than .30 had acceptable discrimination indexes (Kline, 2005). The reliability of the measure was explored using the Cronbach's alpha and the McDonald's omega coefficients, both had to be equal or greater than .70 to be considered adequate (DeVellis, 2017). In addition, the convergent validity of the Brief RCOPE was examined through the average variance extracted (AVE) as recommended by Fornell and Larcker (1981). To establish convergent validity, the AVE had to be equal to or greater than .50 , thus establishing that $50 \%$ or more of the construct's variance was due to its indicators (Fornell \& Bookstein, 1982). Concurrent validity was examined through a Pearson correlation coefficient between the PRC subscale and ratings in areas such as importance of religion, participation in religious activities and participation in private religious practices (e.g., prayer, sacred texts readings) which were extracted from the sociodemographic data form. For the examination of concurrent validity, Pearson correlation values less than .35 were considered weak or low correlations; values between .36 and .67 were considered moderate correlations; values between .68 and .89 were considered high correlations, and, finally, values from .90 onwards were considered very high correlations (Taylor, 1990). Finally, to determine the discriminant validity of each dimension, the value obtained by the individual AVE of each factor had to be higher than the maximum shared variance (MSV) and the average shared variance (ASV).

Using STATA version 15 program (StataCorp, 2017), two CFAs were conducted with the robust maximum likelihood estimation method. Specifically, the Satorra-Bentler adjustments were employed, which is a recommended alternative when data is not normally distributed (Satorra \& Bentler, 2001), as it is the case in the current study's measurement. In order to examine how the proposed model adjusted to the data, the following assessments were conducted: the corrected Chi-square test $\left(\chi_{\mathrm{sb}}^{2}\right)$, the ratio between 
the latter and the degrees of freedom $\left(\chi_{\mathrm{sb}}^{2} / d f\right)$, the corrected root mean square error of approximation $\left(\mathrm{RMSEA}_{\mathrm{sb}}\right)$, the standardized root mean square residual (SRMR), the Tucker-Lewis index (TLI), the comparative fit index (CFI), and the Akaike information criterion (AIC). Values of $\chi_{\mathrm{sb}}^{2}$ Idf lower than 3.0 were indicative of a very good fit for the model, while values of 5.0 or below were considered acceptable. Values of RMSEA less than .08, and SRMR values less than .08 were indicative of an acceptable adjustment of the model (Hooper, Coughlan, \& Mullen, 2008; Kline, 2011). Meanwhile, CFI and TLI values greater than .90 represented acceptable adjustment of the model (Hooper et al., 2008; Kline, 2011). In addition, we used the AIC to compare the models' parsimony. The model with the lower index shows a better adjustment (Schumacker \& Lomax, 2010). For the purpose of examining the statistical significance of the changes in the fit of the models when comparing one to the other, the $\Delta \chi_{\mathrm{sb}}^{2}$ test was conducted (also known as the Satorra-Bentler scaled Chi-square difference test) with a $p$ value of .05 . So, as to evaluate the magnitude or size of such changes, Cohen's $w$ (Cohen, 1988) was employed, a coefficient whose suggested standards for a small (.1), medium (.3), and large $(.5)$ effect are provided in parenthesis.

\section{Results}

Assessment of the normality assumptions

Using SPSS 27.0 (IBM Corp., 2020), the univariate normality assumption was tested using the Kolmogorov-Smirnov and the Shapiro-Wilks test. In both cases, the tests provided evidence that none of the 14 items had a normal distribution ( $p$ $<.001)$. Tests for multivariate normality conducted with STATA also yielded results that revealed violations to the normality assumption [Mardia
mSkewness $=62.61, \chi_{(560)}^{2}=3186.91, p<.001$; Mardia mKurtosis $=325.98, \chi_{(1)}^{2}=1752.54, p<$ .001; Doornik-Hansen test, $\chi_{(28)}^{2}=2443.01, p<$ $.001)$. Given the lack of normality of data, and to correct its effect on the estimation of the standard errors of parameters and global model fit, we used the Satorra-Bentler adjustments as part of the maximum likelihood estimation in STATA.

\section{Confirmatory factor analyses}

To determine the factor structure of the Brief RCOPE (Spanish version), two CFA were performed using the robust maximum likelihood estimation method. The first model evaluated was the one-dimensional model, in which the 14 original items were loaded onto one factor (M1). The CFA showed that the one-factor structure did not obtain adequate goodness of fit indexes. Then, a second model (M2) was examined with a two-correlated factor structure, in which items 1, 2, 3, 4, 5, 6 and 7 loaded on a common factor identified in the literature as PRC, and the items 8 , $9,10,11,12,13$ and 14 loaded on a common factor identified in the literature as NRC. Although this model was superior to the one-factor model (Table 2), item 14 yielded low factor loading ( $<$ $.40)$ in the NRC latent variable and affected the goodness of fit statistics of the model. Therefore, the model was re-specified (see Figure 1) by eliminating this item (M2a). At this stage, the CFA revealed that the revised two-factor model of the Brief RCOPE provided the best adjustment to the data [Corrected $\chi^{2}=142.94, p<.001$; Corrected $\mathrm{RMSEA}=.06 ; \mathrm{SRMR}=.07$; Corrected CFI $=.96$, Corrected TLI $=.95$; AIC $=7966.14$ (see Table $2)$ ]. Observed scores for the 7-item NRC factor and the 6-item version correlated at 99 .

The examination of the statistical significance of the changes in the models using the $\Delta \chi_{\mathrm{sb}}^{2}$ 
test yielded a $p$ value of less than .001 . Cohen's $w$ values for the M1 to M2 and the M2 to M2a comparison, which examined the size of the change in the $\chi_{\mathrm{sb}}^{2}$ value considering the change in degrees of freedom, were 1.30 (large size) and .12 (small size), respectively. This suggests that the differences in the fit indexes between the models examined were not trivial, although were substantially greater from M1 to M2.

Table 2

Goodness-of-fit tests for analyzed models using robust maximum likelihood estimation.

\begin{tabular}{ccccccccc}
\hline Model & $\chi_{\text {sb }}^{2}$ & $\chi_{\text {sb }}^{2} / \boldsymbol{d f}$ & $\mathbf{R M S E A}_{\mathbf{s b}}$ & $\mathbf{S R M R}$ & $\mathbf{C F I}_{\mathbf{s b}}$ & $\mathbf{T L I}_{\mathbf{s b}}$ & AIC & $\Delta \chi_{\mathbf{s b}}^{2}(\Delta \boldsymbol{d f})$ \\
\hline M1 & 701.47 & 9.11 & .16 & .20 & .70 & .64 & 9279.57 & \\
M2 & 194.93 & 2.57 & .07 & .10 & .94 & .93 & 8517.41 & $\Delta \chi_{\mathrm{sb}}^{2}(1)=70.80$ \\
M2a & 142.94 & 2.23 & .06 & .07 & .96 & .95 & 7966.14 & $\Delta \chi_{\mathrm{sb}}^{2}(12)=50.25$ \\
\hline
\end{tabular}

Note. Degrees of freedom for M1, M2 and M2a are 77, 76 and 64, respectively. M1 = one-dimensional model with 14 items; M2 = two-correlated-factors model; M2a = two-correlated-factors model with 13 items (deleting item 14); sb = SatorraBentler adjustments; $\chi_{\mathrm{sb}}^{2}=$ corrected Chi-square Test; $d f=$ degrees of freedom; RMSEA $\mathrm{sb}=$ corrected root mean square error of approximation; $\mathrm{SRMR}=$ standardized root mean square residual; $\mathrm{CFI}_{\mathrm{sb}}=$ corrected comparative fit index; $\mathrm{TLI}_{\mathrm{sb}}=\mathrm{corrected}$ Tucker-Lewis index; AIC $=$ Akaike information criterion; $\Delta \chi_{\mathrm{sb}}^{2}=$ Satorra-Bentler scaled Chi-square difference test; $\chi_{\mathrm{sb}}^{2}$ values and $\Delta \chi_{\mathrm{sb}}^{2}$ tests are significant at $p<.001$.

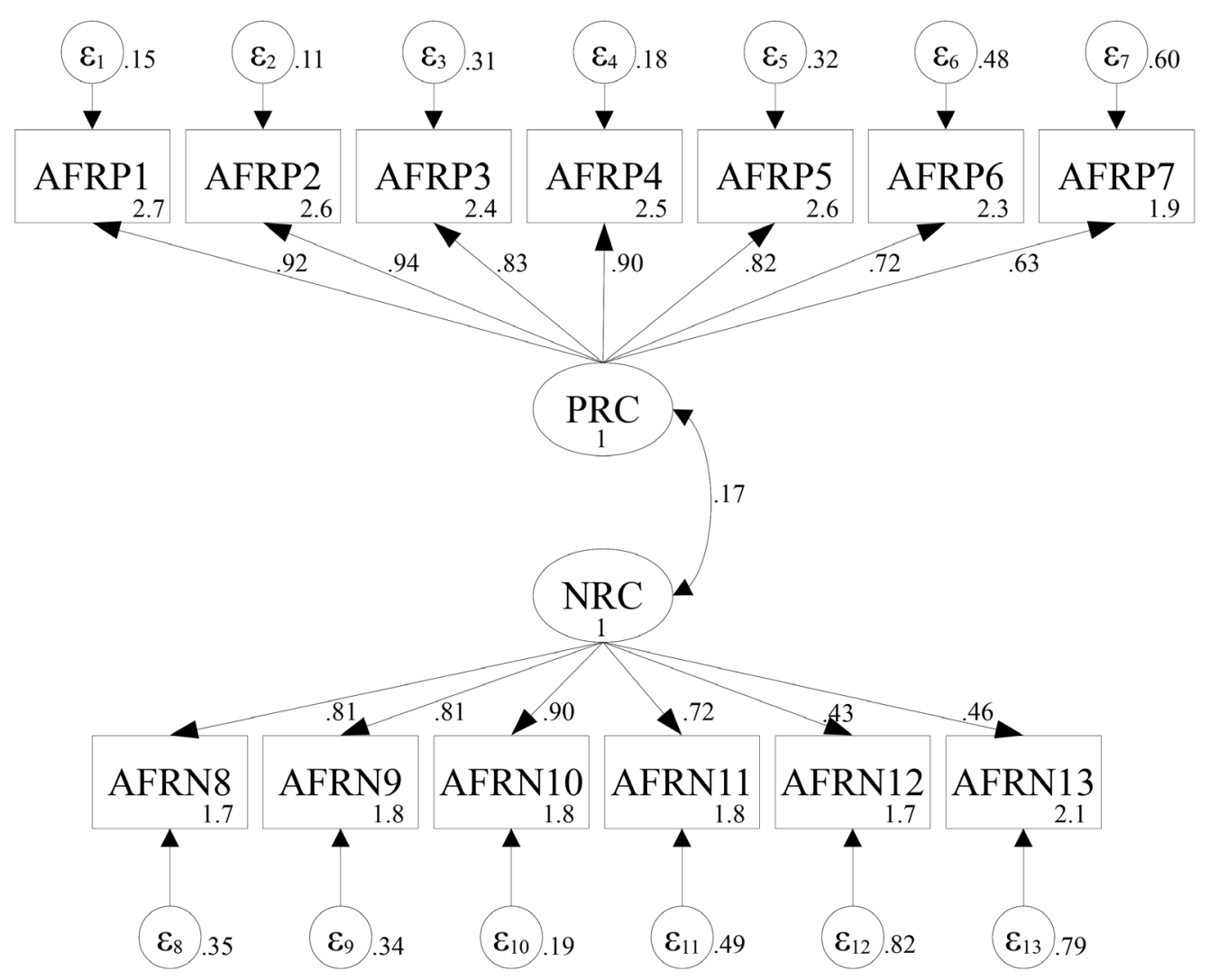

Figure 1

Two-factor structure model of the Brief-Religious Coping Scale. 
Table 3

Average variance extracted, maximum shared variance and average shared variance.

\begin{tabular}{ccccccc}
\hline & Factors & AVE & MSV & ASV & Factor 1 & Factor 2 \\
\hline Brief RCOPE & $\begin{array}{c}\text { Positive Reli- } \\
\text { gious Coping } \\
\text { Negative Reli- } \\
\text { gious Coping }\end{array}$ & .69 & .03 & .03 & 1 & $.23 * * *$ \\
\hline
\end{tabular}

Note. The value below the diagonal represents the correlation between latent factors, while the value above the diagonal represent the correlation among direct scores $\mathrm{AVE}=$ average variance extracted; MSV = maximum shared variance; ASV = average shared variance; Brief R-COPE $=$ Brief Religious Coping Scale. $* * p<.01 ; * * *<.001$.

\section{Reliability and Validity of the Brief-RCOPE}

All the Brief RCOPE items obtained discrimination indexes greater than .30 using the corrected item-total correlation technique as recommended (Kline, 2005). Table 4 shows the discrimination indexes of all items. In terms of the Cronbach's reliability, the PRC subscale obtained an excellent coefficient of .94 and the NRC subscale showed an alpha value of .84. The omega coefficient was .94 for the PRC subscale and .85 for the NRC subscale. The convergent and discriminant validity of the revised two-correlated-factor model was also examined through the AVE, ASV, and MSV. Results showed that the AVE values for both factors were higher than the values of MSV and ASV (see Table 3). Furthermore, the PRC subscale correlated positively and significantly with the importance toward religious belief ( $r=$ $.681, p<.001)$, participation in religious activities $(r=.569, p<.001)$, and participation of private religious practices $(r=.568, p<.001)$. However, the NRC did not correlate with these variables. The results showed that the Brief-RCOPE has a good convergent and discriminatory validity.

\section{Discussion}

The present study aimed to examine the psychometric properties and factor structure of the Brief-RCOPE. The CFA showed a satisfactory fit with the data to the bifactorial structure of the Brief-RCOPE, particularly the model. These results are consistent with other studies conducted in Spanish-speaking countries, such as Chile (García et al., 2021), Argentina (Mezzadra \& Simkin, 2017) and Mexico (Martinez \& Sousa, 2011; Rivera-Ledesma \& Montero-López, 2007), in which the Brief-RCOPE obtained a bifactor structure and good reliability scores. For the revised two-factor model, item 14 was removed given the improvement in the goodness-of-fit of the structure model associated with its exclusion. The relative weakness of item 14 for our sample is similar to findings from Freitas et al. (2015). It should be noted that retaining the item in the NRC would also reduce the alpha coefficient of the factor to .84 , the omega coefficient to .84 , and the AVE to .451. This latter value would be below the requested level (of .50 or more) to support the convergent validity of the NRC factor, and is considered unacceptable. However, the overall results of the revised model replicate the two-dimensional structure considered by the authors in the theoretical construction of the instrument. The two-factor structure of the Brief-RCOPE is closely related to the theoretical foundations and assumptions of the coping model. Furthermore, this instrument obtained adequate Cronbach alpha internal consistency and omega coefficient for the PRC and NRC dimensions, which is con- 
Table 4

Item discrimination indexes and confidence intervals for factor loadings.

\begin{tabular}{|c|c|c|c|c|}
\hline Items of the Brief R-COPE (in Spanish) & $r_{\text {bisl }}$ & $r_{\text {bis } 2}$ & $\beta$ & $95 \% C I_{s b}$ \\
\hline 1. Busqué una conexión más fuerte con Dios. & .87 & & .92 & $.90-.95$ \\
\hline 2. Busqué el amor y cuidado de Dios. & .90 & & .94 & $.93-.96$ \\
\hline 3. Busqué ayuda de Dios para soltar mi coraje. & .80 & & .83 & $.79-.88$ \\
\hline 4. Intenté resolver la situación de la mano de Dios. & .87 & & .90 & $.88-.93$ \\
\hline $\begin{array}{l}\text { 5. Traté de ver cómo Dios podría estar tratando de fortalecerme en esta } \\
\text { situación. }\end{array}$ & .80 & & .82 & $.78-.87$ \\
\hline 6. Pedí perdón por mis pecados. & .71 & & .72 & $.66-.78$ \\
\hline 7. Me enfoqué en la religión para dejar de preocuparme por mis problemas. & .61 & & .63 & $.57-.69$ \\
\hline 8. Me pregunté si Dios me había abandonado. & & .73 & .81 & $.74-.88$ \\
\hline $\begin{array}{l}\text { 9. Sentí que Dios me había castigado por mi falta de devoción (consagración o } \\
\text { fervor). }\end{array}$ & & .71 & .81 & $.74-.89$ \\
\hline 10. Me pregunté qué hice para que Dios me castigara así. & & .80 & .90 & $.86-.95$ \\
\hline 11. Dudé del amor de Dios por mí. & & .66 & .72 & $.62-.81$ \\
\hline 12. Me pregunté si mi iglesia me había abandonado. & & .43 & .43 & $.29-.57$ \\
\hline $\begin{array}{l}\text { 13. Decidí que el diablo (Satanás, Lucifer o el mal) había hecho que esto } \\
\text { sucediera. }\end{array}$ & & .45 & .46 & $.34-.59$ \\
\hline
\end{tabular}

Note. $\mathrm{N}=302 . r_{\text {bis } 1}=$ corrected item-total correlations of items with the positive religious coping factor; $r_{\text {bis } 2}=$ corrected item-total correlations of items with the negative religious coping factor (revised two-factor model); $\beta=$ standardized regression coefficient for each item with its respective factor in the revised two-factor model; $\mathrm{CI}_{\mathrm{sb}}=$ confidence interval with the Satorra-Bentler correction for non-normality; Brief R-COPE = Brief Religious Coping Scale. All coefficients are statistically significant at $p<.001$.

sistent with previous psychometric data about the scale when used with Puerto Ricans (ColónRivera, 2014). All the items obtained an adequate discrimination index. The AVE, MSV and ASV of the subscales were excellent, showing a good concurrent, convergent, and discriminant validity. The data suggest that the Brief-RCOPE is a reliable and valid instrument to measure RC strategies among Puerto Rican adults, particularly if item 14 is excluded.

Despite the fact there is a religious coping measure validated with Puerto Rican samples (González-Rivera \& Pagán-Torres, 2018), the measure is based in the Lazarus and Folkman
(1986) theoretical model of external and internal coping strategies. However, the Brief RCOPE is based on the Pargament theoretical model of positive and negative religious coping strategies (Pargament, 1997). In fact, this is the original model that conceptualized the religious coping strategies as a variable of study. Furthermore, the Brief-RCOPE is a measure widely used in a diversity of countries to measure RC. Therefore, the examination of its reliability, validity and factor structure is essential to promoting the scientific study of religion and spirituality in Puerto Rico, as well as to comparing the findings from studies conducted in other countries to the results ob- 
tained in Puerto Rico.

The Brief-RCOPE may be used in a clinical and research context with clinical and non-clinical samples. In the clinical setting, this measure may be used as a tool for screening religious strategies with high precision and in a short time. Another advantage of this measure is that it provides the opportunity to simultaneously administer a battery of other religious/spiritual and mental health measures (for clinical or research purposes) to explore additional constructs that are positively and negatively associated with RC. The findings provide preliminary evidence of the validity and factor structure of the Brief-RCOPE in the Puerto Rican context. This study adds support to the relevance of conducting additional research in Puerto Rico aimed to evaluate the relationship that PRC and NRC dimensions may have with mental health variables in clinical and non-clinical samples.

Our study has several limitations. First, the participants in the study were not randomly recruited. Instead, we used a non-probabilistic convenience recruitment method. Therefore, our sample is not representative of the Puerto Rican adult population. Second, we did not evaluate the reliability of the instrument over time (using a test-retest strategy). However, we did evaluate Cronbach alpha consistency and McDonald's omega coefficient. In addition, digital recruitment allowed us to amplify the diversity of the sample in terms of sociodemographic characteristics and sample size. Moreover, we used advanced statistical techniques with CFA and an adequate sample size to provide empirical strength to our results. Third, the number of women participants was significantly higher than the number of men participants in this study. Further studies should consider exploring factorial invariance and external validity (correlations with other psychological variables), among other relevant analyses. In addition, future research should consider working with religious samples, as working with university students or the general population is one of the main limitations within the field of Psychology of Religion and Spirituality (Kapuscinski \& Masters, 2010). Despite the limitations mentioned above, the results of this study provide relevant and preliminary information on the psychometric properties and factor structure of the Brief RCOPE in Puerto Rican adults. In addition, we suggest future research to focus on using a diversity of psychological measures that have been positively and negatively associated with RC to examine the nature of PRC and NRC strategies as potential protective or risk factors in diverse populations.

\section{Conclusion}

This is the first study aimed to examine the psychometric properties and factor structure of the Brief-RCOPE in Puerto Ricans. Our findings revealed that the Spanish Brief-RCOPE used in Puerto Rico has excellent psychometric properties and essentially replicates the two-dimensional factor structure. These findings support the applicability of the Brief-RCOPE within the Puerto Rican population. Future studies could further explore the relevance of Brief-RCOPE dimensions with other religious/spiritual measures and mental health outcomes in Puerto Rican clinical (outpatient) and non-clinical samples. This research represents a significant contribution to the scientific study of religion and spirituality in Puerto Rico. In summary, the Brief-RCOPE is a reliable and valid measure, easy to administer, that may be used in any research and/or clinical setting to explore religious coping strategies and their potential status as protective or risk factors on mental health. 


\section{References}

Agosto-Cintrón, N. (1996). Religión y cambio social en Puerto Rico: 1898-1940 [Religion and social change in Puerto Rico]. San Juan, Puerto Rico: Huracán.

Al-Hadethe, A., Hunt, N., Thomas, S., \& Al-Qaysi, A. (2016). Cross-cultural validation and psychometric properties of the Arabic Brief Religious Coping Scale (A-BRCS). Journal of Religion and Health, 55(1), 16-25. doi: 10.1007/s10943-014-9963-7

American Psychiatric Association. (2013). Diagnostic and statistical manual of mental disorders ( $5^{\text {th }}$ ed.). doi: 10.1176/appi.books.9780890425596

Bonelli, R. M., \& Koenig, H. G. (2013). Mental disorders, religion and spirituality 1990 to 2010: A systematic evidence-based review. Journal of Religion and Health, 52(2), 657-673. doi: 10.1007/ s10943-013-9691-4

Cohen, J. (1988). Statistical power analysis for the behavioral sciences ( $2^{\text {nd }}$ ed.). Mahwah, NJ: Lawrence Erlbaum Associates.

Colón-Rivera, Y. (2014). Traducción, adaptación cultural y validación del Brief Religious Coping Scale en una muestra de puertorriqueños/as [Translation, cultural adaptation and validation of the Brief Religious Coping Scale in a sample of Puerto Ricans] (Doctoral Dissertation). Ponce Health Sciences University, Ponce, Puerto Rico.

DeVellis, R. F. (2017). Scale development: Theory and applications (4 ${ }^{\text {th }}$ ed.). Thousand Oaks, CA: Sage.

Esperandio, M. R. G., Escudero, F. T., Fernandes, M. L., \& Pargament, K. I. (2018). Brazilian validation of the Brief Scale for Spiritual/Religious CopingSRCOPE-14. Religions, 9(1), 31. doi: 10.3390/ rel9010031

Fornell, C., \& Bookstein, F. L. (1982). Two structural equation models: LISREL and PLS applied to consumer exit-voice theory. Journal of Marketing Research, 19(4), 440-452. doi: 10.2307/3151718

Fornell, C., \& Larcker, D. F. (1981). Evaluating structural equation models with unobservable variables and measurement error. Journal of Marketing Research, 18(1), 39-50. doi: 10.2307/3151312

Freitas, T. H., Hyphantis, T. N., Andreoulakis, E., Quevedo, J., Miranda, H. L., Alves, G. S., ... \& Carvalho, A. F. (2015). Religious coping and its influence on psychological distress, medication adherence, and quality of life in inflammatory bowel disease. Revista Brasileira de Psiquiatria, 37(3), 219-227. doi: 10.1590/1516-4446-2014-1507

García, F. E., Oyanedel, J. C., Páez, D., \& Arias, P. R. (2021). Psychometric properties of the Brief Religious Coping Scale (Brief-RCOPE) in Chilean adults exposed to stressful events. Journal of Religion and Health, 60(1), 475-487. doi: 10.1007/ s10943-019-00976-7

Gerber, M. M., Boals, A., \& Schuettler, D. (2011). The unique contributions of positive and negative religious coping to posttraumatic growth and PTSD. Psychology of Religion and Spirituality, 3(4), 298307. doi: 10.1037/a0023016

Gonçalves, J. P. B., Lucchetti, G., Menezes, P. R., \& Vallada, H. (2015). Religious and spiritual interventions in mental health care: A systematic review and meta-analysis of randomized controlled clinical trials. Psychological Medicine, 45(14), 2937-2949. doi: 10.1017/S0033291715001166

González-Rivera, J. A., \& Pagán-Torres, O. M. (2018). Desarrollo y validación de un instrumento para medir estrategias de afrontamiento religioso [Development and validation of an instrument for measuring religious coping strategies]. Revista Evaluar, 18(1), 7086. doi: 10.35670/1667-4545.v18.n1.19771

González-Rivera, J. A., Pagán-Torres, O. M., SotoRodríguez, N. E., Rodríguez-Torres, E., MaymíGuadalupe, L. G., \& Rodríguez-Rivera, N. N. (2019). Espiritualidad y religiosidad en revistas puertorriqueñas de psicología: Un análisis bibliométrico [Spirituality and religiosity in Puerto Rican journals of psychology: A bibliometric analysis]. Ciencias de la Conducta, 34(1), 1-38. Retrieved from https:// cienciasdelaconducta.org/index.php/cdc 
Hooper, D., Coughlan, J., \& Mullen, M. R. (2008). Structural equation modelling: Guidelines for determining model fit. The Electronic Journal of Business Research Methods, 6(1), 53-60. Retrieved from https://academic-publishing.org/index.php/ejbrm

IBM Corp. (2020). IBM SPSS Statistics for Windows (Version 27.0). [Computer software]. Armonk, NY: IBM Corp.

Kapuscinski, A. N., \& Masters, K. S. (2010). The current status of measures of spirituality: A critical review of scale development. Psychology of Religion and Spirituality, 2(4), 191-205. doi: 10.1037/a0020498

Kline, R. B. (2011). Principles and practice of structural equation modeling ( $3^{\text {rd }}$ ed.). New York, NY: The Guilford Press.

Kline, T. J. B. (2005). Psychological testing: A practical approach to design and evaluation. Thousand Oaks, CA: Sage.

Koenig, H. G. (2012). Religion, spirituality, and health: The research and clinical implications. International Scholarly Research Notices, Article ID 278730, 1-33. doi: 10.5402/2012/278730

Koenig, H. G. (2015). Religion, spirituality, and health: A review and update. Advances in Mind-Body Medicine, 29(3), 19-26. Retrieved from https://advances-journal.com

Lazarus, R. S., \& Folkman, S. (1986). Estrés y procesos cognitivos [Stress and cognitive proccess]. Barcelona, España: Martínez Roca.

Martinez, N. C., \& Sousa, V. D. (2011). Cross-cultural validation and psychometric evaluation of the Spanish Brief Religious Coping Scale (S-BRCS). Journal of Transcultural Nursing, 22(3), 248-256. doi: $10.1177 / 1043659611404426$

Mezzadra, J., \& Simkin, H. (2017). Validación de la Escala Abreviada de Afrontamiento Religioso BriefRCOPE en el contexto argentino en estudiantes de confesión católica [Validation of the Brief Scale of Religious Coping Brief-RCOPE in the Argentine context in students of catholic denomination]. Revista Evaluar, 17(1), 18-28. doi: 10.35670/1667- 4545.v17.n1.17071

Mohammadzadeh, A., \& Najafi, M. (2016). Factor analysis and validation of the Brief Religious Coping Scale (Brief-RCOPE) in Iranian university students. Mental Health, Religion \& Culture, 19(8), 911-919. doi: 10.1080/13674676.2017.1282445

Oman, D., \& Syme, S. L. (2018). Weighing the evidence: What is revealed by $100+$ meta-analyses and systematic reviews of religion/spirituality and health? In D. Oman (Ed.). Why religion and spirituality matter for public health: Evidence, implications and resources ( $2^{\text {nd }}$ ed., pp. 261-282). doi: 10.1007/978-3-319-73966-3

Pagán-Torres, O. M., \& González-Rivera, J. A. (2019). Desarrollo de medidas religiosas y espirituales en Puerto Rico: Una revisión [Development of religious and spiritual measures in Puerto Rico: A review]. Ciencias de la Conducta, 34(1), 153-182. Retrieved from https://cienciasdelaconducta.org/index.php/cdc

Pagán-Torres, O. M., Sánchez-Galarza, A., Tollinchi-Natali, N., \& González-Rivera, J. A. (2017). Evaluando la relación entre la religiosidad y la salud mental en Puerto Rico: Una revisión sistemática [Evaluating the relationship between religiosity and mental health in Puerto Rico: A systematic review]. Ciencias de la Conducta, 32(1), 128-152. Retrieved from http:// bookshelf.albizu.edu/pdf

Paika, V., Andreoulakis, E., Ntountoulaki, E., Papaioannou, D., Kotsis, K., Siafaka, V., ... \& Hyphantis, T. (2017). The Greek-Orthodox version of the Brief Religious Coping (B-RCOPE) instrument: Psychometric properties in three samples and associations with mental disorders, suicidality, illness perceptions, and quality of life. Annals of General Psychiatry, 16(1). doi: 10.1186/s12991-017-0136-4

Pargament, K. (1997). The psychology of religion and coping. Theory, research, practice. New York, NY: The Guilford Press.

Pargament, K., Feuille, M., \& Burdzy, D. (2011). The Brief RCOPE: Current psychometric status of a short measure of religious coping. Religions, 2(1), 51-76. doi: 
$10.3390 /$ rel2010051

Pargament, K. I., Koenig, H. G., \& Perez, L. M. (2000). The many methods of religious coping: Development and initial validation of the RCOPE. Journal of Clinical Psychology, 56(4), 519-543. doi: 10.1002/(sici)10974679(200004)56:4<519::aid-jclp6>3.0.co;2-1

Pargament, K. I., \& Raiya, H. A. (2007). A decade of research on the psychology of religion and coping: Things we assumed and lessons we learned. Psyche and Logos, 28(2), 742-766. Retrieved from https:// tidsskrift.dk/psyke/article/viewFile/8398/6958

Pargament, K. I., Smith, B. W., Koenig, H. G., \& Perez, L. (1998). Patterns of positive and negative religious coping with major life stressors. Journal for the Scientific Study of Religion, 37(4), 710-724. doi: $10.2307 / 1388152$

Pew Research Center. (november 13, 2014). Religion in Latin America: Widespread change in a historically catholic region. Retrieved from https://www.pewforum.org

Ramirez, S. P., Macêdo, D. S., Sales, P. M. G., Figueiredo, S. M., Daher, E. F., Araújo, S. M., ... \& Carvalho, A. F. (2012). The relationship between religious coping, psychological distress and quality of life in hemodialysis patients. Journal of Psychosomatic Research, 72(2), 129-135. doi: 10.1016/j. jpsychores.2011.11.012

Richards, P. S., \& Bergin, A. E. (Eds.). (2014). Handbook of psychotherapy and religious diversity ( $2^{\text {nd }}$ ed.). Arlintong, VA: American Psychological Association. doi: 10.1037/14371-000

Rivera-Ledesma, A., \& Montero-López, L. M. (2007). Medidas de afrontamiento religioso y espiritualidad en adultos mayores mexicanos [Measures of religious coping and spirituality among Mexican older adults]. Salud Mental, 30(1), 39-47. Retrieved from http://www.revistasaludmental.mx/index.php/ salud_mental/index

Robles-García, R., López-Luna, S., Páez, F., Escamilla, R., Camarena, B., \& Fresán, A. (2014). History of religious delusions and psychosocial functioning among
Mexican patients with paranoid schizophrenia. Journal of Religion and Health, 53(6), 1622-1633. doi: 10.1007/s10943-013-9727-9

Rodríguez-Carrión, D. M., Sayers-Montalvo, S., \& Martínez-Taboas, A. (2011). Contribución del manejo religioso a la calidad de vida y sintomatología depresiva en una muestra de hispanos que tienen un diagnóstico de cáncer [Contribution of religious coping to the quality of life and depressive symptomatology in a sample of Hispanics with a diagnosis of cancer]. Revista Puertorriqueña de Psicología, 22(1), 27-45. Retrieved from http:/www.ojs.repsasppr.net/ index.php/reps

Satorra, A., \& Bentler, P. M. (2001). A scaled difference chi-square test statistic for moment structure analysis. Psychometrika, 66(4), 507-514. doi: 10.1007/ BF02296192

Scarano, F. A. (2008). Puerto Rico: Cinco siglos de historia. New York, NY: McGraw-Hill Interamericana.

Schumacker, R. E., \& Lomax, R. G. (2010). A beginner's guide to structural equation modeling $\left(3^{\mathrm{rd}}\right.$ ed.). Milton Park, Oxforshire: Routledge/Taylor \& Francis Group.

StataCorp. (2017). Stata Statistical Software: Release 15. [Computer software]. StataCorp. Retrieved from https://www.stata.com

Taylor, R. (1990). Interpretation of the correlation coefficient: A basic review. Journal of Diagnostic Medical Sonography, 6(1), 35-39. doi: $10.1177 / 875647939000600106$ 